\title{
Evaluation of Present Lake Environment from Geochemistry of Bottom Sediment of Hartbeespoort Dam, North-West Province, South Africa
}

\author{
Danlami Ibrahim $^{1^{*}} \quad$ Hiroaki Ishiga $^{2}$ \\ 1.Rural Water Supply and Sanitation Department, FCT Waterboard, area 3, Garki, Abuja, Nigeria \\ 2.Department of Earth Science, Shimane University, 1060 Nishikawatsu, Matsue, Shimane, Japan
}

\begin{abstract}
Present Lake Environment of Hartbeespoort Dam was evaluated from Geochemistry of bottom Sediment. Ten (10) bottom sediment samples were collected across the entire Lake. The geochemical composition of the sediment samples was determined using X-ray fluorescence (XRF); trace and major elements determined includes $\mathrm{As}, \mathrm{Pb}$, $\mathrm{Zn}, \mathrm{Cu}, \mathrm{Ni}, \mathrm{Cr}, \mathrm{Fe}_{2} \mathrm{O}_{3}, \mathrm{TiO}_{2}, \mathrm{MnO}, \mathrm{CaO}$ and $\mathrm{P}_{2} \mathrm{O}_{5}$. The trace elements concentrations of the sediment were grouped into three zones base on their spatial distribution. The Western zone of the lake shows a remarkable enrichment in Nickel $(\mathrm{Ni})$ and Chromium $(\mathrm{Cr})$ and could be associated with geogenic source. However high enrichment of phosphate $\left(\mathrm{P}_{2} \mathrm{O}_{5}\right)$ observed in the same zone could be attributed to anthropogenic source, due to agricultural activities on the catchment of Magalies River. Moderate enrichment of $\mathrm{As}, \mathrm{Zn}, \mathrm{Cu}, \mathrm{Cr}$ and $\mathrm{Pb}$ was recorded in the central zone and could be ascribed to entrapment by fine-grained organic and Fe-rich clay deposit in the central part of the lake; this was showcased by the strong positive correlation between the trace elements and $\mathrm{Fe}_{2} \mathrm{O}_{3}$. As, $\mathrm{Zn}, \mathrm{Pb}$ and $\mathrm{Cu}$ were highly enriched in the South - Eastern zone and anthropogenic source could be responsible for the enrichment due to the influence of the Crocodile River. The average concentration of $\mathrm{As}, \mathrm{Pb}, \mathrm{Zn}, \mathrm{Cu}, \mathrm{Ni}$ and $\mathrm{Cr}$ in the sediment were evaluated by comparison with the upper continental crust (UCC), Shale standard (Turekian and Wedepohl, 1961) and Sediment quality guidelines (SQG); the result indicates that $\mathrm{As}, \mathrm{Pb}, \mathrm{Zn}, \mathrm{Cu}$ and $\mathrm{Cr}$ in the study area were above the lowest effect level (LEL) but below the severe affect level (SEL) which shows that the impact on biota is moderate. However, Nickel (Ni) was above the severe effect level and could therefore have severe effect on the aquatic environment.
\end{abstract}

Keywords: aquatic environment, Bottom Sediment, Heavy Metals, Hartbeespoort Dam, X-ray fluorescence

DOI: $10.7176 / \mathrm{JEES} / 9-11-10$

Publication date: November $30^{\text {th }} 2019$

\section{Introduction}

Since ancient civilization Freshwater lakes are acknowledged as centres for cultural development and urbanization, these fresh water bodies are increasingly faced with threat of pollution from agricultural activities, industrialization, waste generation and other related activities as a result of population density (Forstner \& Wittmann, 1979). South Africa (SA) is a semi-arid nation with limited amount of rainfall per annum. Its fresh water resources are relatively scarce and extremely limited when considered on a relative global scale. To check the impending water crises in the country artificial Lakes and impoundments were created through erection of Dams across most major rivers (Department of water affairs (DWA) 2004). Apart from Eutrophication; Chemical and Heavy metal pollution of reservoirs and rivers of SA is of great concern especially where waste water effluents and runoff from urban areas constitutes the significant component of the water balance (Nyirenda et al., 2011; Harding et al, 2010; Adebayo et al, 2014).

Sediments are not just carriers but also potential sources of contaminants in aquatic systems (Fonseca, Patinha, Barriga \& Morais, 2004). Metals trapped within the sediment can be reintroduced into the aquatic system in a bio-available form through remobilization processes commonly triggered by change in physicochemical conditions such as $\mathrm{pH}$, redox potential, concentration of organic complexing agents and ionic strength (Gambrell et al., 1991; Calmano et al., 1993).

Heavy metals are very important in ecological assessment due to their general toxicity and their nonbiodegradable nature (Forstner, 1990). Research have shown that the composition of top sediment layers reflects the current quality of the overlying natural water body. The evaluation of heavy metals concentration in sediments, the physical and chemical forms in which they exist provides information that is crucial in risk assessment, 
conservation and management of natural water system. The focus of this research therefore is to evaluate the Lake environment from geochemistry of the bottom sediment.

\subsection{The Study Area}

Hartbeespoort dam can be described as a warm, monomictic, hypertrophic Lake, located on Longitude $27^{\circ} 51^{\prime} 06.75^{\prime \prime} \mathrm{E}$ and Latitude $25^{\circ} 45^{\prime} 00.64^{\prime \prime} \mathrm{S}$, and about $35 \mathrm{~km}$ west of Pretoria and North of Johannesburg; Sandwiched between the Daspoort Hills on the southern flank and the Magaliesberg mountains on the northern side (Robarts et al., 1982; Scott, Seaman, Connell, Kohlmeyer \& Toerie, 1977). The Dam is in the North-west province of South Africa, close to the border of the Gauteng province. Hartbeespoort Lake is a foremost leisure resort in the province. The lake has $195 \times 106 \mathrm{~m}^{3}$ storage capacity, and occupies a total area of $20 \mathrm{~km}^{2}$ with mean depth of $9.6 \mathrm{~m}$. The Dam is situated in the Crocodile River catchment, downstream of the confluence of the Crocodile, Jukskei and Hennops Rivers which drains the eastern areas of the catchment.

\subsection{Drainage System}

Rivers flow in the study area seasonally; high volume of flow is recorded during the raining season of October to March. The Crocodile River supplies about $90 \%$ of the annual inflow into the lake, the second river with the highest inflow is the Magalies River which drains mostly pastoral area used for grazing, agriculture and nature reserves (NIWR, 1985). Minor tributary stream systems that also supply the Dam includes the Swartspruit and Leeuspruit. The bathymetry and dendritic morphometry of the lake can be attributed to the inflows from the aforementioned rivers. Crocodile river has a catchment area of $29,349 \mathrm{~km}^{2}$ and drains a densely industrialized and urbanized area of the Witwatersrand (Greater Johannesburg Metropolitan Area) as such the return flows especially during the dry season are largely of treated sewage and industrial effluents, this contribute immensely in the supply of noxious waste to the Dam (DWS, 2016).

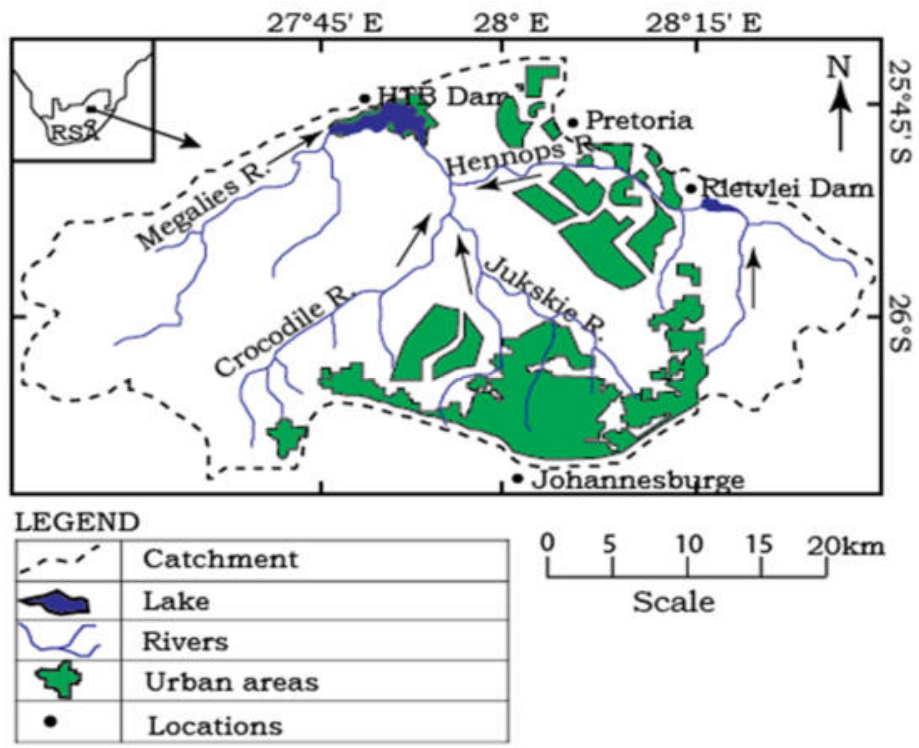

Figure 1: Hartbeespoort Dam and its catchment rivers (Modified after Zohary, 1987) 


\subsection{Geology of the Study Area}

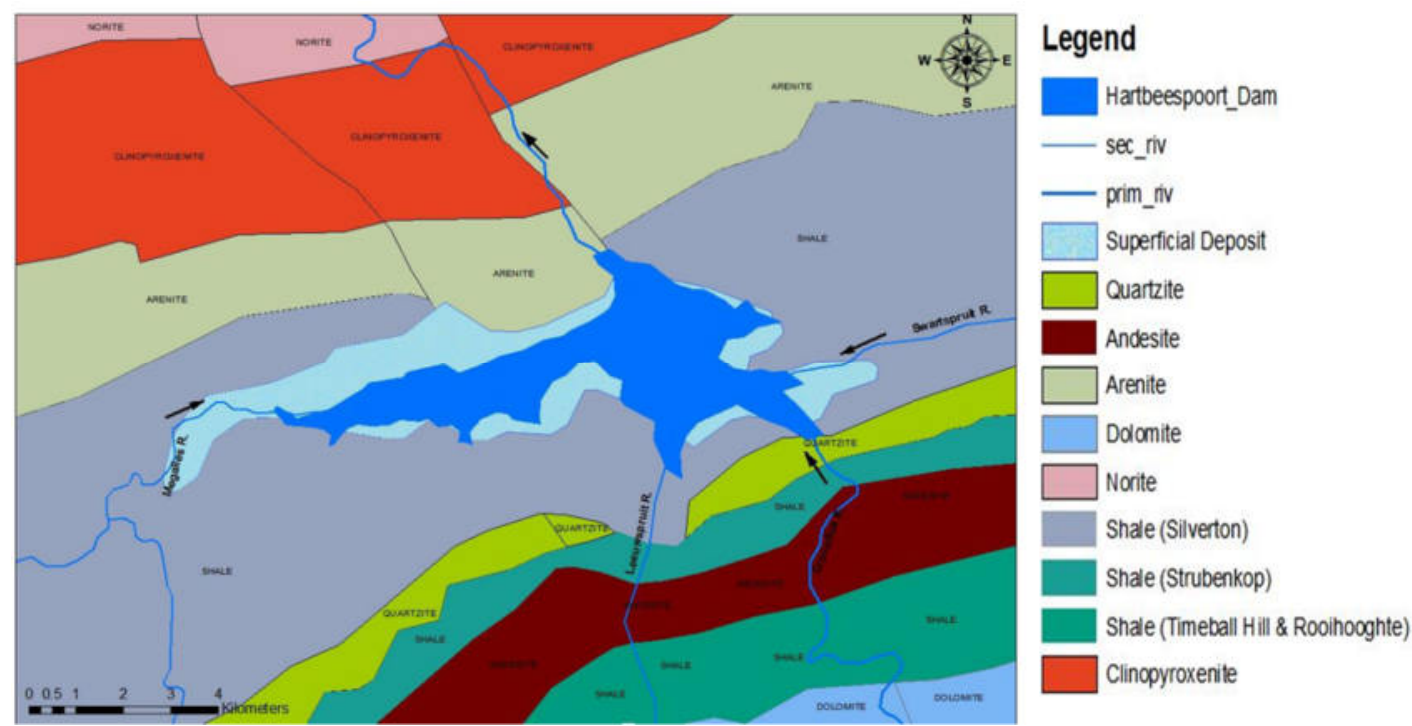

Figure 2: Geological Map of the study area, Council for Geosciences South Africa (ArcGIS, 2018).

Geologically the study area is dominated by rocks of the Pretoria Group which is a subgroup of the Transvaal Sequence. Outcrop in the study area includes the Magaliesberg, Silverton, Hekpoort, Daspoort and Timeball Formations, they run from the northeast to the southwest through the study area and are composed of predominantly quartzite and shales. The dominant landforms that define the geomorphology of the area is the quartzite ridges (Magaliesberg and Witwatersberg), they stand out due to their resistant to weathering. The less resistant shale (Silverton and Timeball formation) forms the Valley between the quartzite ridges which host the Hartbeespoort Dam. Overlying part of the shales is undifferentiated surface deposit (Eriksson et al., 1991)

\subsection{Theoretical Background}

\subsection{Sources of Heavy Metals}

The elemental composition of Lake Bottom sediment depends on the morphology, lithology, and structural settings of the catchment and human activities around it. Generally, the source of Heavy metals to the environment either aquatic or terrestrial can be grouped into two (i) Natural sources (ii) Anthropogenic sources (Callender, 2003).

\subsubsection{Natural Sources}

The major natural source of heavy metal in the environment is weathered and eroded crustal material and from volcanic eruption (This includes ejection of gases into the earth's atmosphere), these two major sources accounts for approximately $80 \%$ of natural source of heavy metals in the environment, while other natural sources such as wildfire and biogenic sources accounts for the remaining 20\% (Alloway, 1995, Callender, 2003).

\subsubsection{Anthropogenic Sources}

The principal sources of Anthropogenic or manmade heavy metals into the environment includes mining and smelting. These activities release Heavy metals into the aquatic environment through tailings and into the earth's atmosphere through metal - enriched dust emission from smelting. Other major anthropogenic sources of metals to the atmosphere includes fossil - fuel combustion, cement production, phosphate mining and municipal waste incineration, these metal contents in the atmosphere often return to the aquatic environment through rainfall and runoff (Callender, 2003). Others sources of anthropogenic heavy metals to the aquatic environment includes sewage sludge, agricultural activities (commercial fertilizers and pesticides, animal waste) and waste water discharge from treatment plants (Nriagu and Pacyna, 1988).

\subsection{Heavy Metals in Freshwater Environments}

In fresh water environment like other aquatic system trace metal often exist as free or complex ions within the water body or adsorbed onto the solid. Sedimentation is considered one of the processes that controls the distribution and partitioning of heavy metals in aquatic systems (Forstner et al., 1986). Heavy metals become 
trapped into the bottom sediment through Adsorption, Ion exchange, Precipitation and Biological activities.

\subsection{Remobilisation of Heavy Metals in Aquatic Environment}

Heavy metals are frequently remobilised in reaction to change in environmental condition and are therefore not permanently bound within the sediment fractions (Fergusson, 1990). The environmental factors that promote the remobilisation of heavy metals in aquatic environment includes change in $\mathrm{pH}$ and redox conditions of water body and the occurrence of Fe - Mn oxyhydroxides (John and Leventhal, 1995).

\subsection{Sediment as a Marker of Heavy Metals Pollution}

The role and importance of sediments in evaluating the quality of an aquatic system is best illustrated in lacustrine environment (Zullig \& Schweiz, 1956). Geochemical analysis of Lake Bottom sediments plays a great role in determining the provenance, distribution extent and likely hazard of heavy metal contamination (Forstner, 1976). Sediments samples from aquatic environment provide means of evaluating the various influences from natural and man-made sources because aquatic sediments are known to document historical events of pollution caused by natural phenomenon, industrial development and population growth.

Studies have shown that water sample analysis can only indicate the intensity of heavy metal concentration at the time of sampling (Wittmann \& Forstner, 1975). Fine particle sediment $(<2 \mu)$ are considered reliable archives of heavy metal pollution in aquatic environment (Forstner and Muller, 1974). The concentration of trace metals in sediments and suspended matter often exceed those in aqueous solution by factor of 1:100, sediment analysis can therefore be used as a tool to identify sources of short-term pollution from anthropogenic sources in aquatic environment (Wittmann \& Forstner, 1975).

\subsection{Methodology}

\subsection{Sediment Sampling}

Bottom sediment samples were taking in March, 2017. A total of 10 samples $(n=10)$ were collected across the entire lake using dredging method with the aid of a boat. The depth of the sampling stations ranges between 7 and $22 \mathrm{~m}$. The sampling stations were located strategically on western, central and south-eastern part of the lake to target sediments from the two major inflows into the dam, which are the Crocodile and the Magalies River. The sediment samples were packaged in polyethylene bags and transported to Shimane University Japan for XRF analysis.

\subsection{Analytical Procedures}

Approximately 50g of each sample were placed in a Pyrex beaker and covered with aluminium foil to prevent contamination. The samples were oven dried at a temperature of $110^{\circ} \mathrm{C}$ for 48 hours. Using an automatic agate mortar and pestle grinder, the samples were ground for about 20 min to breakdown aggregates within the sediment into fine powder. The powdered samples were then compressed into briquettes following the Ogasawara (1987) method by applying a force of $200 \mathrm{kn}$ for $60 \mathrm{~s}$. The concentration of selected major elements such as $\mathrm{TiO}_{2}, \mathrm{Fe}_{2} \mathrm{O}_{3}$, $\mathrm{MnO}, \mathrm{CaO}$ and $\mathrm{P}_{2} \mathrm{O}_{5}(\mathrm{wt} \%$ ) and trace element such as $\mathrm{As}, \mathrm{Pb}, \mathrm{Zn}, \mathrm{Cu}, \mathrm{Ni}$, and $\mathrm{Cr}$, as well as $\mathrm{Zr}$, Th, Sc and TS $(\mathrm{ppm})$ in the sediment were determined by XRF (X-ray fluorescence) in the Department of Geosciences, Shimane University, using RIX-2000 spectrometer (Rigaku Denki Co. Ltd) which is equipped with a Rh-anode X-ray tube. Average errors for all elements analysed are less than $\pm 10 \%$ on a relative scale. 


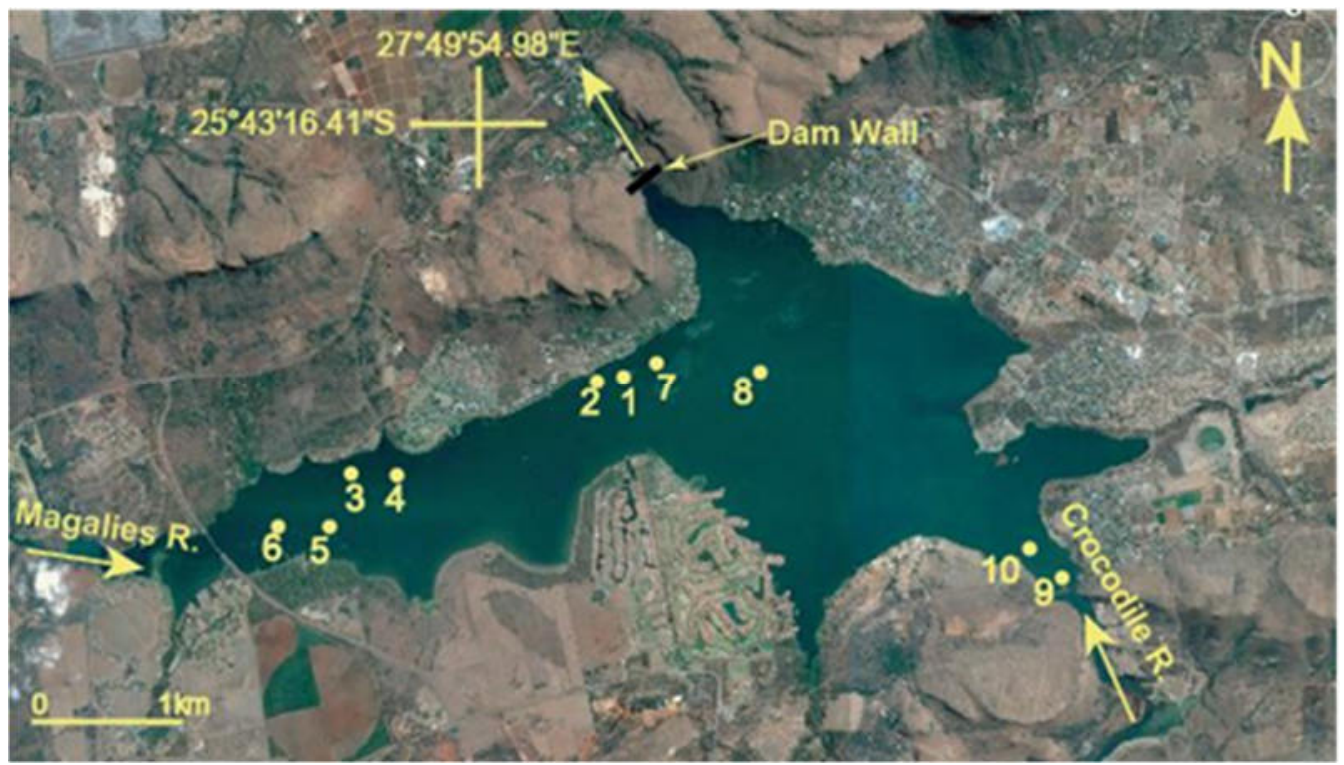

Figure 3: Satellites image of the lake showing the sediment sampling stations and the major inflows.

\subsection{Sediment Characteristics}

Sediment samples collected from the lake can be described as very soft, blackish and slightly silty mud (Fine clay), except for the sample $(n=9)$ which was collected at the inflow area of the Crocodile River, which was brownish mud with a foul smell. The sediment which can be described texturally as fine grained, is rich in organic matter. The clay rich sediment is often layered by Fe (oxy) hydroxides which act as transporters of metallic pollutants by adsorption (Bibi et al., 2006).

\subsection{Result}

\subsection{Concentration of Elements in the Sediment}

The elemental compositions of the bottom sediment showing the abundance of selected major and Trace elements are summarized in Table 5.1; The range between the values of the geochemical data varies considerably which can be attributed to the source of the sediment to Dam, and the kind of pollutants transported by the catchment rivers to the impoundment.

\subsection{Spatial distribution of elements Concentration across the study area}

The concentration of metals in the bottom sediment of Hartbeespoort Dam, represented graphically to show the spatial distribution of the enrichment in the study area indicates that the heavy metal enrichment can be divided into three zones; (i) The western zone (ii) The Central zone (iii) The south-eastern zone. This is based on the sampling pattern of this study.

\subsubsection{The Western Zone}

Nickel (Ni) and Chromium (Cr) were enriched in the western zone of the Dam; these enrichments could be associated with geogenic source because Magalies River flowing into the dam from the western zone and its tributaries (Skeerpoort and Leeuspruit Rivers) transport sediments rich in these metals (Wittmann \& Forstner, 1975). Phosphate $\left(\mathrm{P}_{2} \mathrm{O}_{5}\right)$ was enriched also in the western zone, this can be attributed to Anthropogenic source because the Magalies River and its tributaries drains mostly pastoral area used for grazing, agriculture and nature reserves (NIWR, 1985). 
Table 5.1 Geochemical composition of Hartbeespoort Dam Bottom sediment

\begin{tabular}{|c|c|c|c|c|c|c|c|c|c|c|c|c|c|}
\hline \multirow{2}{*}{$\begin{array}{l}\text { Sample } \\
\text { No: }\end{array}$} & \multicolumn{7}{|c|}{ Trace elements (ppm) } & \multicolumn{6}{|c|}{ Major elements (wt \%) } \\
\hline & As & $\mathrm{Pb}$ & $\mathrm{Zn}$ & $\mathrm{Cu}$ & $\mathrm{Ni}$ & $\mathrm{Cr}$ & $\mathrm{V}$ & TS & $\mathrm{TiO}_{2}$ & $\mathrm{Fe}_{2} \mathrm{O}_{3}$ & $\mathrm{MnO}$ & $\mathrm{CaO}$ & $\mathrm{P}_{2} \mathrm{O}_{5}$ \\
\hline HTBD 1 & 4 & 14 & 70 & 17.1 & 59.7 & 471 & 73.9 & 3440 & 0.45 & 2.39 & 0.08 & 2.2 & 0.46 \\
\hline HTBD 2 & 4.4 & 11 & 44 & 17.4 & 64.3 & 538.5 & 104.6 & 1723 & 0.69 & 4.89 & 0.1 & 0.96 & 0.2 \\
\hline HTBD 3 & 3.3 & 9.5 & 42 & 15.7 & 71.8 & 686.6 & 100.6 & 1483 & 0.62 & 4.47 & 0.09 & 0.97 & 0.13 \\
\hline HTBD 4 & 7.2 & 18 & 102 & 59.3 & 138.7 & 670.6 & 199.9 & 4851 & 0.76 & 8.49 & 0.17 & 3.45 & 0.45 \\
\hline HTBD 5 & 7.8 & 23 & 127 & 80.7 & 151.2 & 616.5 & 223.7 & 4689 & 0.91 & 9.77 & 0.2 & 5.42 & 0.44 \\
\hline HTBD 6 & 7.1 & 21 & 118 & 67 & 141.6 & 617.1 & 209.7 & 4577 & 0.89 & 8.62 & 0.2 & 6.75 & 0.41 \\
\hline HTBD 7 & 8.4 & 38 & 178 & 86.1 & 156.2 & 512.5 & 252.7 & 3854 & 0.97 & 11.2 & 0.24 & 1.71 & 0.25 \\
\hline HTBD 8 & 8.5 & 43 & 204 & 90.4 & 158.8 & 475.3 & 247.6 & 4349 & 1.04 & 11.29 & 0.26 & 1.21 & 0.22 \\
\hline HTBD 9 & 5.8 & 34 & 160 & 53.9 & 75.7 & 241.3 & 114.3 & 1342 & 0.66 & 5.09 & 0.13 & 0.98 & 0.17 \\
\hline HTBD10 & 10.2 & 57 & 287 & 107.2 & 134.5 & 371.7 & 204.2 & 1426 & 1.01 & 9.85 & 0.16 & 1.06 & 0.23 \\
\hline
\end{tabular}

* HTBD = Hartbeespoort Dam, No = Number

\subsubsection{The Central Zone}

The central zone down to the wall of the Dam is the deepest part of the impoundment, it hosts very fine sediments rich in clay at its bottom. $\mathrm{As}, \mathrm{Zn}, \mathrm{Cu}, \mathrm{Pb}$, and $\mathrm{Cr}$ were all moderately enriched in this zone, the trend of the enrichment however was towards South-eastern zone of the Dam with exception Cr which enrichment trend is towards the western zone. Ni was exceptionally very high at the central zone. These enrichments in the central zone can be attributed to Fe-rich clay deposit in the deepest part of the impoundment. $\mathrm{Fe}$ - oxide is considered an excellent trapper of trace metals (Diallo \& Ishiga, 2016).

\subsubsection{The South - Eastern Zone}

The south - eastern zone of the dam which is the inflow route of the Crocodile River, display a striking enrichment of $\mathrm{As}, \mathrm{Zn}, \mathrm{Pb}$ and $\mathrm{Cu}$. Wittmann \&Forstner (1975) reportes that the sediments of the crocodile river are enriched in $\mathrm{Zn}, \mathrm{Pb}, \mathrm{Hg}$ and $\mathrm{Cd}$ and attributed the enrichment to anthropogenic source. The enrichment of these environmentally sensitive elements $(\mathrm{As}, \mathrm{Zn}, \mathrm{Pb}$ and $\mathrm{Cu}$ ) in the south - eastern zone of the Dam could therefore be attributed to human induced activities.

Table 5.2 Correlations between the elements in the sediment of Hartbeespoort Dam

\begin{tabular}{|c|c|c|c|c|c|c|c|c|c|c|c|c|c|}
\hline & As & $\mathrm{Pb}$ & $\mathrm{Zn}$ & $\mathrm{Cu}$ & $\mathrm{Ni}$ & $\mathrm{Cr}$ & V & $\mathrm{TS}$ & $\mathrm{TiO}_{2}$ & $\mathrm{Fe}_{2} \mathrm{O}_{3}$ & $\mathrm{MnO}$ & $\mathrm{CaO}$ & $\mathrm{P}_{2} \mathrm{O}_{5}$ \\
\hline As & 1.00 & & & & & & & & & & & & \\
\hline $\mathrm{Pb}$ & 0.85 & 1.00 & & & & & & & & & & & \\
\hline $\mathrm{Zn}$ & 0.89 & 0.99 & 1.00 & & & & & & & & & & \\
\hline $\mathrm{Cu}$ & 0.99 & 0.87 & 0.90 & 1.00 & & & & & & & & & \\
\hline $\mathrm{Ni}$ & 0.87 & 0.55 & 0.61 & 0.88 & 1.00 & & & & & & & & \\
\hline $\mathrm{Cr}$ & -0.22 & -0.62 & -0.57 & -0.25 & 0.19 & 1.00 & & & & & & & \\
\hline V & 0.86 & 0.59 & 0.63 & 0.89 & 0.99 & 0.14 & 1.00 & & & & & & \\
\hline $\mathrm{TS}$ & 0.34 & -0.09 & -0.02 & 0.33 & 0.68 & 0.49 & 0.62 & 1.00 & & & & & \\
\hline $\mathrm{TiO}_{2}$ & 0.90 & 0.73 & 0.75 & 0.91 & 0.90 & -0.02 & 0.93 & 0.34 & 1.00 & & & & \\
\hline $\mathrm{Fe}_{2} \mathrm{O}_{3}$ & 0.90 & 0.66 & 0.69 & 0.91 & 0.97 & 0.08 & 0.99 & 0.51 & 0.97 & 1.00 & & & \\
\hline $\mathrm{MnO}$ & 0.79 & 0.57 & 0.59 & 0.83 & 0.94 & 0.05 & 0.96 & 0.64 & 0.88 & 0.94 & 1.00 & & \\
\hline $\mathrm{CaO}$ & 0.18 & -0.25 & -0.14 & 0.19 & 0.44 & 0.49 & 0.37 & 0.71 & 0.19 & 0.26 & 0.32 & 1.00 & \\
\hline $\mathrm{P}_{2} \mathrm{O}_{5}$ & 0.11 & -0.27 & -0.17 & 0.06 & 0.28 & 0.37 & 0.18 & 0.76 & -0.09 & 0.06 & 0.12 & 0.76 & 1.00 \\
\hline
\end{tabular}

* Bold values highlight strong correlations. 

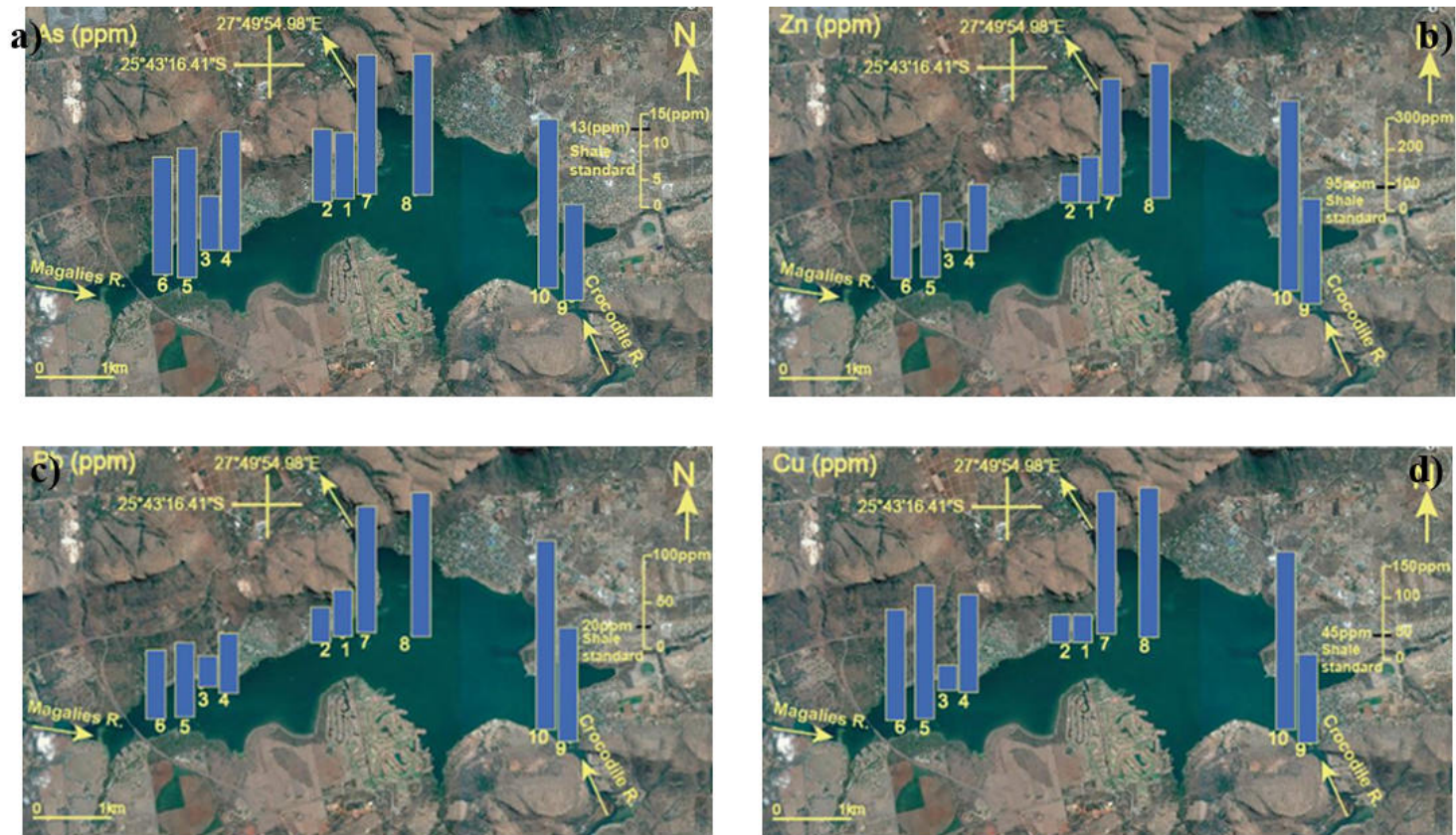

Figure 4 (a,b,c,d): Concentration of $\mathrm{As}, \mathrm{Zn}, \mathrm{Pb}$ and $\mathrm{Cu}$ in bottom sediment of HTBD, Metal Values of Shale standard (Turekian and Wedepohl, 1961) is used as relative scale.
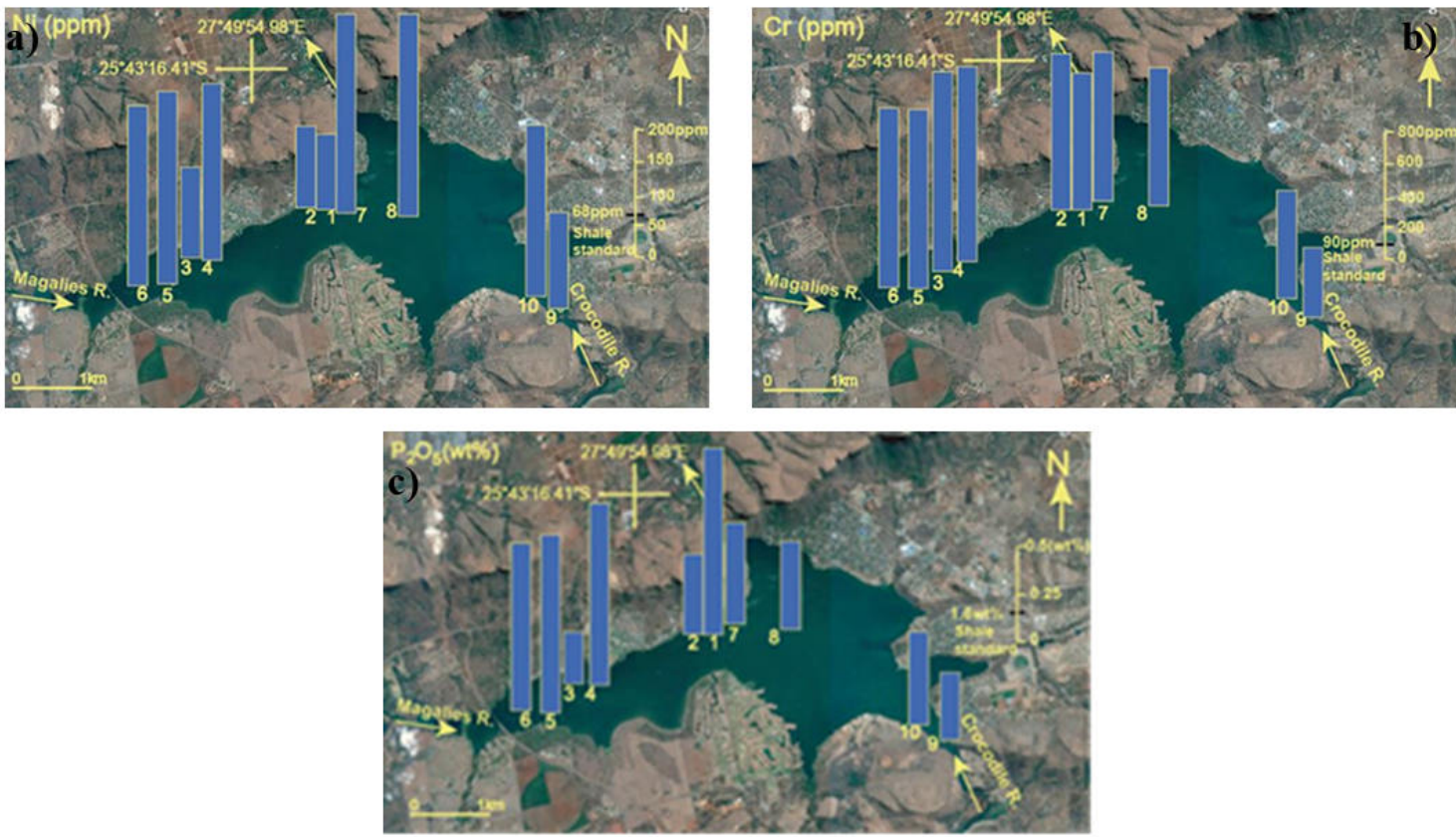

Figure $5(\mathrm{a}, \mathrm{b}, \mathrm{c})$ : Concentration of $\mathrm{Ni}, \mathrm{Cr}$ and $\mathrm{P}_{2} \mathrm{O}_{5}$ in bottom sediment of HTBD, Metal Values of Shale standard (Turekian and Wedepohl, 1961) is used as relative scale for $\mathrm{Ni}$ and $\mathrm{Cr}$ while Metal Values of Shale standard (PAAS) is used as relative scale for $\mathrm{P}_{2} \mathrm{O}_{5}$ (Condie, 1993).

\subsection{Comparison of Metal Concentration with Sediment Quality Guidelines}

Studies have shown that high concentration of heavy metals in bottom sediment of aquatic environment can cause adverse biological effect, without the quality of water necessarily exceeding the quality standard (Bibi et al., 2006). In this study attempts were made to establish the present condition of the aquatic environment by comparing the $\mathrm{As}, \mathrm{Pb}, \mathrm{Zn}, \mathrm{Cu}, \mathrm{Ni}$, and $\mathrm{Cr}$ concentration in the Hartbeespoort Dam (Table 5.2) with upper continental crust (UCC), 
the shale standard by Turekian and Wedepohl (1961) and sediment quality scale developed by the New York State Department of Environmental Conservation (NYSDEC, 1999).

The NYSDEC (1999) developed the lowest effect level (LEL) and the severe effect level (SEL) benchmark or scale. Based on this scale if the LEL is exceeded, the negative impact of the metal on biota is considered moderate; if the SEL is exceeded, the impact on biota is considered severe.

The average concentration of $\mathrm{As}, \mathrm{Pb}, \mathrm{Zn}, \mathrm{Cu}, \mathrm{Ni}$, and $\mathrm{Cr}$ in the bottom sediment of study area (Table 5.2) is greater than the upper continental crust (UCC) scale and the shale standard by Turekian and Wedepohl (1961). In terms of effect on the aquatic biota $\mathrm{As}, \mathrm{Pb}, \mathrm{Zn}, \mathrm{Cu}$ and $\mathrm{Cr}$ were above the lowest effect level (LEL) but below the severe effect level, the impact of these metals on the biota could be considered moderate. However, the average concentration of $\mathrm{Ni}(115.4 \mathrm{ppm})$ was twofold the severe effect level and could therefore have severe effect on the biota.

Table 5.2 Heavy metal concentration in the bottom sediment of the study area (ppm) compared to Sediment quality standards.

\begin{tabular}{llllll} 
Metals & $\mathrm{UCC}^{\mathrm{a}}$ & $\mathrm{T} \mathrm{\&} \mathrm{K}^{\mathrm{b}}$ & $\mathrm{LEL}^{\mathrm{c}}$ & $\mathrm{SEL}^{\mathrm{d}}$ & HTBD \\
\hline $\mathrm{As}$ & 1.5 & 1.6 & 6 & 33 & 6.65 \\
$\mathrm{~Pb}$ & 20 & 20 & 31 & 110 & 26.85 \\
$\mathrm{Zn}$ & 71 & 95 & 120 & 270 & 133.2 \\
$\mathrm{Cu}$ & 25 & 45 & 16 & 110 & 59.48 \\
$\mathrm{Ni}$ & 20 & 68 & 16 & 50 & 115.4 \\
$\mathrm{Cr}$ & 35 & 90 & 26 & 110 & 520 \\
\hline
\end{tabular}

${ }^{a}$ Upper continental crust (UCC; Taylor and McLennan, 1985)

b Turekian and Wedepohl, 1961 (Shale Standard)

${ }^{c}$ Lowest effect level (LEL, NYSDEC 1999)

d Severe effect level (SEL; NYSDEC 1999)

$\mathrm{HTBD}=$ Hartbeespoort Dam.

\section{Conclusion}

The Heavy metal concentration in Hartbeespoort dam was determined through bottom sediment sample analysis. The bottom sediment is in a reduced state due to the stratified nature of the lake. The trace elements concentrations of the sediment were grouped into three zones base on their spatial distribution. The Western zone of the lake shows a remarkable enrichment in Nickel (Ni) and Chromium $(\mathrm{Cr})$ and could be associated with geogenic source. However high enrichment of phosphate $\left(\mathrm{P}_{2} \mathrm{O}_{5}\right)$ observed in the zone could be attributed to anthropogenic source, due to agricultural activities on the catchment of Magalies River which flows into the dam through the western zone. Moderate enrichment of $\mathrm{As}, \mathrm{Zn}, \mathrm{Cu}, \mathrm{Cr}$ and $\mathrm{Pb}$ was recorded in the central zone and is ascribed to entrapment by Fe-rich clay deposit in the central part of the lake. $\mathrm{As}, \mathrm{Zn}, \mathrm{Pb}$ and $\mathrm{Cu}$ were highly enriched in the South Eastern zone and anthropogenic source could be responsible for the enrichment due to the influence of the Crocodile River.

The sediment quality guidelines used in this study indicates that $\mathrm{As}, \mathrm{Pb}, \mathrm{Zn}, \mathrm{Cu}$ and $\mathrm{Cr}$ in the study area were above the lowest effect level (LEL) but below the severe affect level which shows that the impact on biota is moderate. However, Nickel (Ni) was above the severe effect level and could therefore have severe effect on the Biota.

Fundamentally the result of this research showcases the environmental condition of the Hartbeespoort Dam, by providing important information regarding the heavy metal concentration of the Dam which could be used by the authority concern to assess the potential risks and the remobilization tendency of the trace metals in the Dam.

\section{Acknowledgments}

This research was financially supported by Japan international cooperation agency (JICA), The Authors profound gratitude also goes to Geoscience Department, Shimane University Japan, for providing the conducive environment and equipment for the research and Finally thanks to Department of Soil and Plant Protection in the Ministry of Agriculture, Forestry and Fisheries in Japan for making it easy to import the samples. 


\section{REFERENCES}

Adebayo, S.A., Shai, L.J., Cholo, M.C., Anderson, R. \& Du Toit, D. (2014). Assessment of the pro-inflammatory activity of water sampled from major water treatment facilities in the greater Pretoria region. Water SA 40: 379-383.

Alloway B. J. (1995) Heavy Metals in Soils 2nd edn. Blackie Academic and Professional, London, UK.

Bibi H. M., Ahmed F. and Ishiga H. (2006) Assessment of metal concentrations in lake sediments of southwest Japan based on sediment quality guidelines. Environ Geol 52:625-639. DOI 10.1007/s00254-006-0492-X.

Callender E (2003) Heavy Metals in the Environment - Historical Trends. In: Holland H and Turekian K (ed.) Treatise on Geochemistry. Rhode Island, Elsevier,67-105

Calmano W, Hong J and Forstner U (1993) Binding and mobilisation of heavy metals in contaminated sediments affected by $\mathrm{pH}$ and redox potential, Water, Science and Technology, 28 (8-9): 223-235.

Department of water affaires (2004). National Water Resource Strategy. First Edition. Pretoria, South Africa. Available from: http://www.dwaf.gov.za/Documents/Policies/NWRS/Default.htm.

Diallo, I. M, and Ishiga H. (2016). Geochemical Distribution, Enrichment, and Potential Toxicity of Trace Metals in the Surface Sediments of Okinawa Mangrove, Southwest Japan. Environment and Natural Resources Research; Vol. 6, No. 3

DWA. (2009). About the Hartbeespoort Dam. http://www.dwaf.gov.za/Harties.

Eriksson, P.G., Schreiber, U.M., Van der Neut, M. (1991) A review of the sedimentology of the Early Proterozoic Pretoria Group, Transvaal Sequence, South Africa: implications for tectonic set- ting. J. Afr. Earth Sci. 13:107-119.

Fergusson J (1990) The heavy elements: Chemistry, environmental impact and health effects. Permagon Press, New Zealand, 1-614

Fonseca R., Patinha C., Barriga F and Morais M. (2004). Geochemistry of metals in the bottom sediments of tropical dam reservoirs in San- Francisco River (Três Marias, MG) and Tocantins River (Tucuruí, PA), Brazil.

Forstner U, Ahlf W, Calmano W, Kersten M and Salomons W (1986) Mobility of Heavy Metals in Dredged Harbor Sediments. In: Sly P (ed.) Sediments and Water Interactions. Netherlands, Springer,371-380

Forstner U., Wittman G.T.W (1979), Metal pollution in aquatic environment. Springer-Verlag Berlin.

Forstner, U (1990) Inorganic Sediment Chemistry and Element Speciation. In: Baudo, R and Muntau, H (eds.) Sediments: Chemistry and toxicity of in-place - pollutants. Lewis publishers, inc. Ann Arbor, Boca Raton.

Forstner, U., (1976). Lake sediments as indicators of heavy metal pollution. Naturwissenschaften 63: 465-470.

Forstner, U., Muller, G. (1974): Schwermetallanreicherungen in datierten Sedimentkernen aus dem Bodensee und aus dem Tegernsee. Tschermaks Mineral. Petrogr. Mitt. 21, 145-163.

Gambrell R, Wiesepape J, Patrick W and Duff M (1991) The effects of pH, redox, and salinity on metal release from a contaminated sediment, Water, Air, and Soil Pollution, 57-58: 359-367.

Harding, W.R., Downing, T.G., Van Ginkel, C.E. \& Moolman, A.P.M. (2010). An overview of cyanobacterial research and management in South Africa post-2000. Water SA 35: 479-484.

John D and Leventhal J (1995) Bioavailability of metals, In: Preliminary compilation of descriptive geoenvironmental mineral deposit models Report. U.S. Geological Survey, Denver, 10-18

NIWR, (1985). The limnology of Hartbeespoort Dam. South African National Scientific Programs Report. No. 110.

Nriagu J. O. and Pacyna J. M. (1988) Quantitative assessment of worldwide contamination of air, water, and soils by trace metals. Nature 33, 134-139.

Nyirenda, M., Itumeleng, P.D., Dzoma, B.M., Motsei, L.E., Ndou, R.V. \& Bakunzi, F.R. (2011). Heavy metal levels in water, catfish (Clarias gariepinus) and African fish eagle (Haliaeetus vocifer) specimens from the municipal wastewater fed Modimola dam outside Mafikeng city, North West Province, South Africa. Life Science Journal. 8: 47-52.

NYSDEC (New York State Department of Environmental Conservation) (1999) Technical guidance for screening contaminated sediments. NYSDEC, Department of Fish, Wildlife and Marine Resources, Albany, NY.

Robarts.R.D., Ashton.P.J., Thornton.J.A., Taussig.H.J. and Sephton,L.M. (1982), Overturn in a hypertrophic, warm, monomictic impoundment (Hartbeespoort Dam, South Africa), Hydrobiologia, 97, 209-224. 
Scott W. E., Seaman M. T., Connell A. D. , Kohlmeyer S. I. \& Toerien D. F. (1977), The Limnology Of Some South African Impoundments I. The Physico-Chemical Limnology of Hartbeespoort Dam, Journal of the Limnological Society of Southern Africa, 3:2, 43-58, DOI: 10.1080/03779688.1977.9633135.

Taylor SR, McLennan SM (1985) The continental crust: its composition and evolution. Blackwell, Oxford, pp 312

Turekian, K. K. and Wedepohl, K. H. (1961). Distribution of the elements in some major units of the earth's crust. Bull. Geol. Soc. Amer., Vol. 72, 175 - 192.

Wittmann G. T. W., Forstner U. (1975) Metal enrichment of sediments in inland waters - The Hartbeespoort Dam. Water S.A. Vol. 1 No: 2, p76 - 82.

Zullig, H., Schweiz, Z. (1956): Sedimente als Ausdruck des Zustandes eines Gewassers.. Hydrol. 18, 7-143. 